$1-3-2018$

\title{
Civil War, Economic Governance \& State Reconstruction in the Arab Middle East
}

Steven Heydemann

Smith College, sheydemann@smith.edu

Follow this and additional works at: https://scholarworks.smith.edu/mes_facpubs

Part of the Near Eastern Languages and Societies Commons

\section{Recommended Citation}

Heydemann, Steven, "Civil War, Economic Governance \& State Reconstruction in the Arab Middle East" (2018). Middle East Studies: Faculty Publications, Smith College, Northampton, MA.

https://scholarworks.smith.edu/mes_facpubs/4 


\title{
Civil War, Economic Governance \& State Reconstruction in the Arab Middle East
}

\author{
Steven Heydemann
}

\begin{abstract}
Civil wars currently underway in Libya, Syria, and Yemen demonstrate that patterns of economic governance during violent conflict exhibit significant continuity with prewar practices, raising important questions along three lines. First, violent conflict may disrupt prewar practices less than is often assumed. Second, continuity in governance highlights the limits of state fragility frameworks for postconflict reconstruction that view violent conflict as creating space for institutional reform. Third, continuity of prewar governance practices has important implications for the relationship between sovereignty, governance, and conflict resolution. Civil wars in the Middle East have not created conditions conducive to reconceptualizing sovereignty or decoupling sovereignty and governance. Rather, parties to conflict compete to capture and monopolize the benefits that flow from international recognition. Under these conditions, civil wars in the Middle East will not yield easily to negotiated solutions. Moreover, to the extent that wartime economic orders reflect deeply institutionalized norms and practices, postconflict conditions will limit possibilities for interventions defined in terms of overcoming state fragility.
\end{abstract}

STEVEN HEYDEMANN is the Janet Wright Ketcham 1953 Professor in Middle East Studies at Smith College and a Nonresident Senior Fellow at the Brookings Institution Center for Middle East Policy. He is the author of Authoritarianism in Syria: Institutions and Social Conflict (1999), editor of War, Institutions, and Social Change in the Middle East (2000), and coeditor of Middle East Authoritarianisms: Governance, Contestation, and Regime Resilience in Syria and Iran (with Reinoud Leenders, 2013).
$\mathrm{I}_{\mathrm{f}}$ If war is the continuation of policy by other means, then civil war can be seen as the continuation of governance, not by other means as Carl von Clausewitz remarked, but by the same means. The civil wars currently underway in Libya, Syria, and Yemen demonstrate that patterns of governance during violent conflict - the practices used by insurgent and regime forces to maintain order in their areas of control - differ less from prewar practices than might be expected. In all three of these Middle Eastern cases, the legacies of prewar governance are especially evident in how regime and insurgent forces construct wartime economic orders to advance their political agendas. For both researchers and practitioners, the persistence of prewar governance practices under conditions of violent conflict raises important questions, along three distinct but related lines.

(C) 2018 by the American Academy of Arts \& Sciences doi:10.1162/DAED_a_00473 
First, it challenges understandings of civil war as marking a rupture in governance: violent conflict may disrupt prewar practices less than is often assumed. Civil wars may not, as some have argued, give rise to governance practices that differ sharply from those present during peacetime. Furthermore, evidence of continuity also calls into question the extent to which rebel or insurgent forms of governance differ from those practiced by embattled regimes. The reliance of rebels and regimes on similar modes of economic governance reduces the likelihood that insurgents will mitigate causes of violent conflict, such as corruption, predation, or exclusion, or, as some have claimed, contribute to the development of inclusive, participatory postconflict political and economic orders. ${ }^{1}$

Second, continuity between prewar and wartime practices, especially in the domain of economic governance, highlights the limits of state fragility frameworks intended to improve the performance of poorly governed states. Typically defined as the result of dysfunctional institutions that produce negative social, political, and economic outcomes, fragility is widely believed to increase the likelihood of violent conflict. Fragile states are especially vulnerable to internal strains that weak and flawed institutions cannot manage or mitigate. ${ }^{2}$ Violent conflicts not only signal the breakdown of such institutions, but create possibilities for more effective, inclusive, and accountable postconflict institutions to emerge.

Fostering the development of such institutions has become a major preoccupation of development and postconflict practitioners. ${ }^{3}$ However, the persistence of prewar norms and practices as well as the continued reliance of regimes and insurgents alike on prewar institutions during periods of violent conflict raise significant questions about the usefulness of fragilitybased frameworks. William Reno has critically and helpfully assessed fragility- based frameworks, yet does so on the as- Steven sumption that civil war implies state col- Heydemann lapse. 4 Civil wars in the Middle East complicate this starting point. Conflict, in some cases at least, does far less than is argued in the literature to weaken prewar norms and practices that are viewed as causes of fragility. As international affairs scholar Ariel Ahram has noted: "those interested in state failure tend to misconstrue or ignore...the feasibility and desirability of repairing state strength." 5 Civil wars in the Middle East make clear that violent conflict can deepen the perceived utility of institutions that were intentionally structured to support authoritarian, exclusionary, and predatory systems of rule. Such conditions challenge the feasibility of approaches to postconflict reconstruction that reflect the underlying assumptions of fragility frameworks. Tanja Börzel and Sonja Grimm have pointed out that even in cases in which the European Union, a powerful external actor, intervenes to strengthen institutional effectiveness in its immediate neighborhood, efforts often fall short. ${ }^{6}$ Middle East and North Africa (MENA) region experiences reinforce the view that we reconsider just how fragile the institutions are that generate outcomes typically associated with fragility, even in extreme cases such as Libya and Yemen, where prewar states ranked very highly on indicators of weakness.

Third, the continuity of prewar practices affects the relationship between sovereignty, governance, and conflict resolution. ${ }^{7}$ In the Arab Middle East, where state boundaries are routinely described as artificial, violent conflict is often characterized as the result of failed nation-building or, in international studies scholar Benjamin Miller's terms, a sharp incongruence between "the division of the region into territorial states and the national aspirations and political identifications of the region's peoples." 8 Libya, Syria, and Yemen are all states in which rigid, unitary 
Civil War, conceptions of sovereignty suppressed the aspirations and identifications of citizens, and played a role in launching national uprisings that evolved from protest movements into violent conflicts.

In all three cases, protracted conflict has been accompanied by proposals to redefine the terms of sovereignty, including various forms of local autonomy, federalism, decentralization, and even state partition. ${ }^{9} \mathrm{How}-$ ever, civil wars in the Middle East underscore the difficulties that confront attempts to advance alternative conceptions of state sovereignty as solutions to violent conflict. These alternatives often rest on the assumption that governance and sovereignty are separable. They assume that the relationship between the two can take a variety of forms. Yet as evidenced by the determination with which warring parties in Libya, Syria, and Yemen struggle to control state institutions and state functions, governance becomes a potent measure of a regime's sovereign standing. And sovereignty itself is far too significant a resource to dilute through political frameworks that would weaken the power of a central authority to govern. In keeping with the view expressed by Hendrik Spruyt, unitary, Westphalian conceptions of sovereignty among parties to civil war in the Middle East show few signs of yielding to formulas that erode the benefits that international recognition generates for sovereigns. ${ }^{10}$

Thus, civil wars in the Middle East have not created conditions conducive to reconceptualizing sovereignty or decoupling sovereignty and governance. Rather, they have been accompanied by the weaponization of sovereignty, with parties to conflict competing to capture and monopolize the benefits that flow from international recognition. This process has received significant support, moreover, from the increasing influence in the international system of authoritarian actors, including Russia, China, and Iran, who forcefully advocate a rigid, unitary, centralized, and indivisible definition of sovereignty. Those who are recognized internationally as sovereign thus acquire immediate advantages that vastly increase the likelihood of their military success and weaken their incentives to compromise or, in some cases, negotiate.

C ontinuity between prewar and wartime practices is visible in how both recognized authorities and insurgent forces in Libya, Syria, and Yemen manage the challenges of economic governance. In all three countries, the descent into civil war has been accompanied not by the breakdown of prewar, authoritarian, criminal, and predatory economic norms and practices, but by their redeployment to serve wartime requirements. Despite claims that view violent conflict as rupturing prewar practice, such continuity is not surprising. "Conflict," as political scientist Paul Staniland has noted, "does not play out on a blank slate that actors can make and remake as they wish. Instead, the past shapes leaders' options in the present." 11

The past casts an especially long shadow on the civil wars examined in this essay, in which the prewar economic institutions and practices of authoritarian regimes turned out to be particularly well-suited to the requirements of insurgent forces. Yet research literature on civil war as well as the prevailing practitioner frameworks for mitigating violent conflict and rebuilding war-torn societies and economies have not taken adequate account of the persistence of authoritarian norms and practices during civil war. They overlook the implications for how external actors respond to some acute forms of violent conflict and misdiagnose the conflict-resolution strategies that will be needed to end conflict and establish durable peace.

This emphasis on continuity in economic governance in Libya, Syria, and Yemen is not to suggest that economies are indiffer- 
ent to conflict, or did not undergo meaningful change as violence escalated and civil war took hold. In all three cases, national markets have been destroyed by war and replaced by patchworks of fragmented, highly localized markets that are nonetheless integrated into translocal networks of trade and exchange, including trade between adversaries across conflict lines. ${ }^{12}$ Patterns of international trade have been sharply altered by war. So have overall levels of economic productivity and output. In all three countries, manufacturing and agricultural sectors have been devastated and oil production and exports have declined sharply, while control over natural resources and predatory opportunities (smuggling, extortion, human trafficking) generate intense conflict between opposing factions. ${ }^{13}$

Moreover, continuity at the level of practices does not imply continuity in the composition or configuration of economic actors. What is evident, however, from the experiences of all three countries is that the economic norms and practices developed by authoritarian regimes before war persist during conflict and affect both how conflicts end and how postconflict political economies are organized. In all three cases, informal economic institutions resemble those described by Reno and Vanda Felbab-Brown: they were pervasive and personalistic, often exerting more influence over economic outcomes than formal state institutions and economic policies. ${ }^{14}$ In all three, prewar economic norms and practices included a culture of impunity for privileged economic actors, predatory and coercive forms of resource extraction, porous boundaries between formal and informal economic activity and between licit and illicit practices, as well as dispersed, diffuse frameworks of economic authority in which state functions such as regulation and service provision were delegated to nonstate agents. ${ }^{15}$ In all three, economic governance was organized not to ensure the provision of public goods to all citizens, but Steven to control and allocate access to what can Heydemann only be described as semipublic goods to select categories of citizens, typically on the basis of ascriptive criteria. ${ }^{16}$ These economic norms and practices were accompanied by social norms, institutions, and political practices that further eroded the distinction between prewar and wartime conditions, including decentralization of control over the means of violence and delegation (or de facto privatization) of the authority to tax and extract resources from citizens. ${ }^{17}$

E vidence of continuity in economic governance has significant implications along several dimensions. It matters for how we think about the relationship between states and insurgent movements, how insurgencies are organized and sustain themselves, and the challenges that confront postconflict stabilization and reconstruction. Three such dimensions are explored in this essay.

First, such evidence calls into question a foundational assumption of research literature on rebel governance and on the political economy of civil war: that state-based forms of economic governance are distinct from those constructed by insurgents, and that conflict economies exhibit unique attributes that differentiate them from prewar conditions of economic "normalcy." According to international affairs scholars Karen Ballentine and Jake Sherman,

Recent scholarship has identified several features unique to the economies of civil war: they are parasitic, because they are dominated by rent-seeking and the extraction and trade of primary products, rather than by value adding economic activities; they are illicit, insofar as they depend heavily on black and gray markets that operate outside and at the expense of legal and formal economic activity of the state; and they are predatory - that is, they are based on the deliberate and systematic use of violence to acquire assets, control trade, and exploit labor. ${ }^{18}$ 
Civil War,

Economic Governance \& State Reconstruction in the Arab Middle East
This attempt to draw sharp distinctions between civil war economies that exhibit "unique features" and prewar economies that engage in "value adding economic activities" is difficult to sustain given how prewar political economies were organized in Syria, Libya, and Yemen. In all three, the authoritarian economic orders that existed prior to the onset of civil war-arrangements that government scholar Daniel Brumberg describes as "protection rackets" - undermine the claim that violent conflicts are the cause of predation, rent-seeking, and a disregard for the longterm requirements of economic and social development in what were previously well-governed economies. ${ }^{19}$

Not only do wartime economic orders in Libya, Syria, and Yemen exhibit significant continuity with prewar practices, they also display striking similarities across areas of each country held by regime or opposition forces. To be sure, there are notable differences between the wartime economic orders that have emerged in areas under the control of regimes or recognized authorities and those in rebel-held territories. ${ }^{20}$ Not least, regimes benefit from their standing as recognized sovereign authorities, with all the advantages this confers. ${ }^{21}$ In many important respects, however, civil war in Syria, Libya, and Yemen has amplified and expanded the economic logics and practices that were commonplace before 2011. These legacy effects flowing from the political economies of prewar authoritarian regimes highlight the extent to which wartime economic orders are influenced by and sustain prewar economic practices, none of which reflected the conditions of advanced capitalist economies, in which the rule of law functions, formal institutions of economic governance are relevant, and elements of accountability are present.

Instead, prewar Libya, Syria, and Yemen can best be defined as corrupt, predatory, and crony capitalist political economies with low accountability and transparency and weak rule of law. In all three, as in other authoritarian regimes in the MENA region, the political requirements of regime survival trumped concerns with economic and social development. ${ }^{22}$ State elites engaged routinely in illicit practices to enrich themselves at public expense. Criminal economic networks were tightly integrated into and operated as prominent features of state-regime-business relations among civilian elites and their bureaucratic and military counterparts, who often controlled significant business interests in their own right. ${ }^{23}$ Economic policy, anchored in long-term mistrust of the private sector by regimes, was designed to make private economic activity legible to, controllable by, and subject to the predatory intervention of state authorities.

These prewar economic practices influenced how wartime economic orders would take shape once protest movements collapsed into violent conflict. In each case, prewar systems of economic governance socialized citizens into economic norms and behaviors that supported antiregime mobilization. Over time, citizens honed economic skills, knowledge, and capacities that helped launch and sustain antiregime protests. These included how to conceal economic resources and activities from state authorities, and a reliance on clandestine, formally illicit modes of exchange organized through informal networks based on family, kin, or other ascriptive ties that are difficult for outsiders to penetrate.

From 2011 onward, informal networks facilitated clandestine strategies of popular mobilization for antiregime protests as violence escalated. ${ }^{24}$ They also proved highly adaptive in the development of formal and informal insurgent funding networks that linked armed opposition groups in Syria to the governments and populations of Gulf Cooperation Council states. The clandestine and networked character of Syria's 
prewar economy also enabled communications flows, enhanced trust among participants in the uprising, and eased bargaining and negotiations among adversaries and competitors that have mitigated the economic effects of war. Adversaries have negotiated agreements to distribute power and water supplies across conflict lines and buy and sell oil, wheat, and other essential goods - such as vegetables from Idlib to Deir al-Zour in Syria - across territory controlled by competing armed groups. ${ }^{25}$

After more than six years of conflict, the informal economic networks that the Assad regime cultivated through local agents, extending opportunities for private profit through tolerated illicit activities in exchange for loyalty and service as regime enforcers, had not only endured, but had also emerged as central to the dispersed strategy of control and coercion that grew stronger as the Syrian state and regime contracted. The most detailed study available of the transformation of regime-linked criminal networks into loyalist militias that acquire semiformal status, even while they benefit from significant autonomy and have enormous influence over economic and political affairs in their areas of operation, provides compelling evidence of this metamorphosis. ${ }^{26}$ Such arrangements give the regime flexibility in deploying highly decentralized networks of local warlords to enforce its authority and extract resources from local populations. ${ }^{27}$

As in any conflict zone, these conditions produced opportunities for profit alongside the vast destruction the war has wrought. These have emerged, in part, through competition between the regime and opposition for access to scarce commodities, including wheat and oil. According to accounts of officials, the regime has been able to outbid the opposition. In doing so, it has created incentives for new networks of mediators to emerge who broker the transfer of goods across conflict lines. ${ }^{28}$
Economic opportunities have also aris- Steven en in the trafficking of the vast quantities Heydemann of goods looted from the homes of those displaced by war, and by exploiting prewar illicit trading networks to meet the needs that conflict has created. ${ }^{29}$ Researchers at the London School of Economics, for example, have identified a vibrant market in automobiles that sprang up in Deraa in Southern Syria near the Jordanian border - an area known before the war for its extensive smuggling networks. ${ }^{30}$ In the north of the country, Syrian-Turkish trade is believed to have returned to prewar levels, through both formal trade channels and extensive informal, illicit trade networks that have thrived despite the militarization of the border and its periodic closure by Turkey. ${ }^{31}$ The Syrian-Lebanese border zone has provided similar opportunities for trade, smuggling, refugee flows, and support operations for insurgent armed groups, exploiting wellestablished (and often regime-supported) illicit trading networks.

Similar evidence of continuity, linkages between state and nonstate actors, the blending of legal and criminal activities, and the utility of prewar economic practices during episodes of violent conflict are all evident in the resurgence of human trafficking networks in Libya. Along a key transit route into Southern Europe, loyalist tribal networks closely linked to the Gaddafi regime were implicated in the rise of human trafficking that Libya experienced in the 200os. In 2008, the Libyan government agreed to clamp down on trafficking in exchange for financial assistance from the Berlusconi government in Italy. A leading European think tank described the trafficking activity during this period as "a criminal activity conducted by specific organisations in connection with the formal state institutions." 32 When the Gaddafi regime was overthrown in 2011, human trafficking surged once again. Yet in the regime's absence, illicit trafficking became more high- 
Civil War, ly decentralized, with multiple competing

Economic

Governance \&

State Recon-

struction in the

Arab Middle

East

smuggling networks - linked to warring factions in Libya's civil war - battling for control over key routes. ${ }^{33}$ As Gaddafi's loyalists lost their privileged access to a broad range of predatory activities, nearly all parties to the Libyan conflict engaged in racketeering, the "protection" of trade, and other forms of extortion to generate the revenue needed to sustain their participation in conflict.

Yemen also exhibits persistent patterns of predatory and illicit practices by state and nonstate actors that have proven to be highly functional in sustaining violent conflict. As in Syria and Libya, such practices are widespread, including within the recognized government led by President Abdrabbuh Mansour Hadi. They involve combinations of cooperation and competition among actors across conflict lines, linkages between state and nonstate actors, blending of licit and illicit activities, and the mobilization of cross-cutting economic networks that emerged during prewar periods and complicate efforts to map specific activities by tribe, region, or sect. For example, classified U.S. diplomatic cables released by Wikileaks include an assessment from May 2005 from the U.S. Embassy in Sana' a noting direct participation by a powerful Yemeni general, Ali Mohsen al-Ahmar - who defected from the government of then-President Ali Abdullah Saleh in early 2011 and was appointed deputy commander of Yemen's Armed Forces in January 2016 under President Hadi - in a vast smuggling enterprise. ${ }^{34}$ Mohsen's illicit but sanctioned activities extended across the country, were supported and sustained by several units of the armed forces, and relied on collaboration from wide-ranging networks of actors, including tribes formally identified as regime adversaries. While notable for its scale and scope, the predatory frameworks that Mohsen exploited were widespread in prewar Yemen.
The escalation of violence in Yemen in mid-2014, following the collapse of a National Dialogue process intended to chart the country's transition to a more inclusive, participatory form of rule, amplified the role of these prewar economic practices. According to Freedom House, the "network of corruption and patronage established under Saleh remained entrenched in public institutions." 35 As violence shattered Yemen's fragile economy, with fragmented state institutions, massive levels of food insecurity, and more than two million Yemenis displaced, illicit, predatory economic practices have grown in importance. Armed factions, including Houthi forces as well as those associated with the recognized government, are deeply implicated in the smuggling of weapons, food, and pharmaceuticals, as well as human trafficking. Indeed, trafficking networks that previously moved migrants from the Horn of Africa across Yemen and into Saudi Arabia - flows that continue in the midst of conflict - have diversified and now also move Yemenis who can afford to leave to the Horn of Africa. ${ }^{36}$

In none of the three cases explored here has conflict led to a significant shift in prewar practices of economic governance. Instead, practices evident in all three before the most recent outbreaks of violence have persisted, providing parties to the conflict especially those associated with internationally recognized sovereign authorities with the means to sustain their military activities. Middle Eastern cases undermine claims that violent conflicts cause a rupture with prewar economic practices, and that they give rise to political economies that exhibit attributes that are unique in being parasitic, illicit, and predatory. Based on evidence from Syria, Libya, and Yemen, such claims are simply untenable.

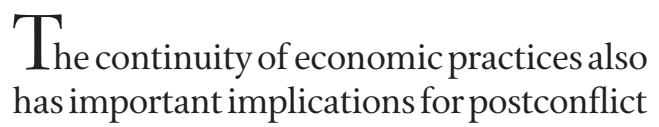


reconstruction. Simply put, whether civil war ends in a negotiated settlement or military victory, local actors have few incentives to give up wartime economic orders. These economic orders took shape before the onset of conflict, helped make it possible for local actors to sustain military operations, delivered significant benefits to designated sovereigns, and created new categories of actors with a stake in their perpetuation. These factors complicate approaches to postconflict reconstruction that link the onset of civil war to state fragility, and find the remedy to fragility in the development of state institutions that possess attributes of high-quality governance, but threaten the power and wealth of leading actors. In addition, in Libya, Syria, and Yemen, as in many other predatory, authoritarian regimes, the institutional arrangements associated with state fragility are not the failed outcomes of state-building processes that sought, but fell short of achieving, inclusive, participatory, and developmentally effective forms of governance. Rather, in Libya under Muammar Gaddafi, in Syria under Hafez al-Assad and Bashar al-Assad, and in Yemen under Ali Abdullah Saleh, state-building reflected the strategic choices of incumbents who designed governance institutions to express exclusionary, repressive, and predatory preferences.

The state institutions that resulted from such processes did not lack capacity, nor were they fragile. They provided incumbents with the organizational means to construct durable, repressive-exclusionary systems of rule, appropriate resources and redistribute them through mechanisms that privileged regime loyalists, and consolidate social pacts between regimes and select categories of citizens. ${ }^{37}$ Conflict is indeed an indicator of regime dysfunction, and the limits of the economic and political orders on which they rest. Yet if the Middle East is any example, these indicators have not been read as signals of the need for reform, either by incumbents or by most challengers.

When the mass protests of 2011 led to armed insurgencies and civil war in these three cases, insurgent forces appropriated and adapted prewar institutions of economic governance. In their struggles for control of the state, powerful insurgent movements - including Ansar al-Sharia in Libya, the Houthi movement in Yemen, and Ahrar al-Sham, Hayat Tahrir al-Sham, and the Islamic State in Syria - reproduced the authoritarian characteristics associated with state fragility: exclusion, predation, corruption, illegality, and informality. When the Assad regime relinquished authority in Northeast Syria in 2012 to the Kurdish Democratic Union Party (PYD), the PYD immediately "replicated past regime behavior, focusing on maintaining a secure hold of this strategic geographical area at the expense of effective governance." ${ }^{8}$ Thus, violent conflict in Syria, Libya, and Yemen has not, as political economist Leonard Wantchekon has argued, "annihilated the authoritarian political situation that led to war," thereby creating possibilities for political and economic reconstruction along more inclusive and participatory lines. ${ }^{39}$ Unlike cases in which wartime governance is linked to processes of democratization, in these three cases, it has tended to reproduce prewar, authoritarian norms and practices of economic governance. ${ }^{40}$

One example of this phenomenon from each of the cases explored in this essay should suffice to make the point. In September 2014, an assessment on Yemen published by the Atlantic Council expressed concern that key political actors were reproducing pre-uprising patterns of governance:

Instead of reshaping the political order to bring in new political voices, address corruption, and introduce responsive and accountable governance, partisan interests have largely paralyzed the transitional gov- 
Civil War,

Economic

Governance \&

State Recon-

struction in the

Arab Middle

East ernment, perpetuating the elite-dominated politics of old Sana'a and its tribal allies. ${ }^{41}$

In December 2015, the International Crisis Group warned that revolution and the overthrow of the Gaddafi regime in Libya had done little to alter the political economy of natural resource management in the country:

One aspect of the hydrocarbon dispute is a challenge to the centralised model of political and economic governance developed around oil and gas resources that was crucial to the old regime's power. But corruption that greased patronage networks was at that model's centre, and corrupt energy sector practices have increased. ${ }^{42}$

In the Syrian case, in which prewar state institutions were more developed and have experienced less degradation than in Yemen or Libya, we find even more robust patterns of institutional continuity and the persistence of the corrupt, predatory attributes described above, attributes mirrored in many instances in the governance institutions created by the opposition. ${ }^{43}$ As in Libya and Yemen, conflict has narrowed, rather than expanded, opportunities for the reform of state practices. 44

From a fragility perspective, these regime adaptations to wartime conditions have consequences that are not only counterproductive, but undermine the capacity of external actors to uphold their own standards of accountability, legality, and transparency. In 2016, for example, researchers and journalists brought to light the extent to which UN humanitarian assistance programs in Syria had become complicit in the corrupt and predatory norms that define the regime's economic governance. ${ }^{45}$ Rather than an international institution moving a "fragile state" toward norms of good governance, its intervention instead corrupted its own operating norms and practices.
With neither regimes nor insurgents committed to economic inclusion, transparency, or accountability, postconflict processes of economic reconstruction that draw on recommendations from the state fragility literature are unlikely to succeed. Civil wars in the Middle East highlight the chasm that divides the assumptions underlying fragility-based strategies of conflict resolution from the realities of conflict dynamics. Where local actors view existing institutions as critical for their survival, where incentives to endorse processes of institutional reform are weak, where international actors themselves exhibit little commitment to good governance, fragility-based frameworks face insurmountable obstacles.

C ontinuity in patterns of economic governance from prewar to wartime conditions also highlights how tightly civil war has linked sovereignty and governance in the Middle East, reducing prospects for political settlements that envision a decoupling of the two. In the recent literature on sovereignty, limited statehood, and governance, researchers have identified a wide range of nonstate governance frameworks that emerge in which the domestic sovereignty of states is weak or entirely absent. ${ }^{46}$ These frameworks are often presented as expanding opportunities for state-based, nonstate, and external actors to "share sovereignty," address deficits in the provision of public goods, and resolve violent conflicts. 47 Yet the civil wars in Libya, Syria, and Yemen have pushed in the opposite direction, narrowing opportunities for flexible conceptions of sovereignty to take hold and giving recognized authorities incentives to sustain prewar governance practices.

By any measure, these three cases reflect the attributes of limited statehood. In all three, nonstate actors have become centrally involved in critical aspects of economic governance, and recognized authorities have themselves cultivated vast semi- 
autonomous, nonstate economic networks to extract revenue from war-torn and fragmented economies. Nonetheless, civil war in the Middle East has also increased the significance regimes and insurgents attach to unitary, Westphalian conceptions of sovereignty. It has reinforced the imperative of sovereignty as a weapon that can be wielded against challengers, or used to buttress the political, diplomatic, and economic resources to which a recognized authority has access. Even as the functions of economic governance diffuse and dissipate beyond the direct control of states, recognized authorities aggressively assert their economic authority and their exclusive right to undertake the economic functions that legitimate their standing as sovereign. Economic governance as an expression of sovereignty not only constrains possibilities for reallocating economic functions as part of a political settlement, it rewards recognized authorities that behave as if they possess the economic sovereignty they claim, and hold fast to rigid, centralized control over economic governance.

Thus, sovereignty is fiercely defended in Libya, Syria, and Yemen by regimes that claim the legitimacy and authority, as well as the legal protections and prerogatives, associated with international recognition. In all three cases, as in many authoritarian regimes, recognized governments invest heavily in domestic institutions that affirm their standing as sovereign, including courts and constitutions. ${ }^{48}$ They staunchly defend their claims to sovereignty in their relations with external actors and exploit such claims to extract resources from the international system. They legitimate foreign military interventions - by both state and nonstate actors - as entitlements of sovereignty. In all three cases, moreover, internationally recognized authorities legitimate their standing in part through their capacity to perform the economic governance functions associated with Westpha- lian sovereignty. ${ }^{49}$ They maintain central banks, issue economic regulations, sign Steven Heydemann contracts with other states, invest in public works, take on sovereign debt, pay salaries to public-sector employees, even in areas controlled by insurgents, and insist on their prerogative to tax.

To be sure, the intensity with which recognized authorities pursue the roles and functions of statehood and governmentality bear little resemblance to the reality of fragmented, contested, and dispersed economic control in all three countries. In none of the three do recognized governments possess the domestic attributes associated with sovereignty: they lack exclusive control over territory, populations, and natural resources; they do not possess a monopoly over the legitimate use of violence; and they do not exercise legal or economic authority throughout the prewar borders of the state. ${ }^{50}$ In all three cases, processes of economic fragmentation have been accelerated by regimes that have actively delegated sovereign functions of economic governance to a variety of nonstate and external actors. Moreover, rebel movements have adopted the economic norms and practices of the regimes they seek to displace, deepening the fragmentation of national economies.

As wartime economic orders take hold and fragmented, "translocal" markets become consolidated, the prospects for reestablishing central governments that possess the attributes of economic sovereignty are diminished. Yet this has not tempered the drive for control over formal economic governance by recognized authorities, or made them more responsive to proposals for economic decentralization. In the Yemeni case, for example, regime and insurgent actors compete for control over national financial institutions, splintering authority over the central bank and government ministries. In Libya, warring parties have struggled to assert their authority over the country's most significant economic 
Civil War, institution, the National Oil Company, and

to control the "oil crescent," in which oil production is concentrated. In early 2017, forces associated with General Khalifa Haftar, who opposes the internationally recognized Government of National Accord (GNA) based in Tripoli, seized control of the region. Reflecting the dire implications of this move for Libya's recognized government, Haftar's actions provoked sharp criticism from the UN and Western governments for undermining the sovereignty of the GNA. General Haftar, meanwhile, cultivated support from Russia to enhance his own claims to sovereign authority, using the control of Libya's oil-producing areas by his forces to strengthen his bid for international recognition.

In contrast, moderate opposition forces in Syria declined to establish "national" institutions of economic governance challenging those of the Assad regime. Such a course, they argued, would only encourage external actors to seek the partition of the country - an outcome that Syria's experience of colonial rule placed beyond the scope of legitimate possibilities. Instead, highly localized wartime economic orders have emerged, with controlling militias exerting significant authority over economic activities in a given area, relying on a familiar repertoire of informal, illicit economic practices to generate revenue. The Islamic State, however, explicitly mimicked the economic forms of a modern state to bolster its claims to sovereignty as an Islamic caliphate, even while engaging in predatory and criminal practices of economic governance that resembled those of regimes and rebels alike.

Indeed, rebel-controlled local economies have proliferated in all three countries, as armed groups imposed their authority over economic activities in areas under their control and adopted combinations of coercion, criminality, and cooperation with local populations to extract the revenues needed to sustain themselves in power and continue to wage war.

These trends hold significant implications for the relationship between governance, limited statehood, and sovereignty. On the one hand, the tenuousness of domestic sovereignty in all three of the civil wars examined here has amplified and hardened the determination of recognized authorities to defend their sovereign standing. It reinforces their refusal to contemplate alternatives to a rigid, unitary, and centralized conception of sovereignty. It also drives continuity in prewar governance practices, especially with respect to economic governance, which becomes a marker of their capacity to fulfill their responsibilities as sovereign and fend off competing claims from rivals. On the other hand, the sovereign standing of recognized authorities also empowers them to engage with impunity in a wide range of illicit, corrupt, and predatory economic practices, devolve authority over economic governance to nonstate actors, and otherwise exploit limited statehood to their own advantage.

Thus, under wartime conditions, governance, sovereignty, and limited statehood become more tightly coupled. Civil wars in the Middle East offer few prospects for strategies of conflict resolution that rest on decoupling governance and sovereignty, or on the acceptance of flexible, plural, decentralized conceptions of sovereignty. In all three of the cases, proposals have been advanced, calling for various forms of decentralization, federalism, or local autonomy within existing state borders, and for powersharing arrangements at the national level. Yet in each of these cases, leading political actors on all sides have rejected such proposals as threats to the integrity and sovereignty of the nation, or as conspiratorial attempts by imperial powers to redraw state boundaries or partition and thus weaken Arab states. In the Syrian case, for example, the Assad regime, the opposition Syrian Na- 
tional Coalition, and the opposition Higher Negotiation Committee have all rejected proposals for political arrangements that they believe would compromise the sovereignty and integrity of the Syrian state. In all three cases, sovereignty claims empower external spoilers, embolden recognized governments and insurgents to adopt hardline positions, and encourage political actors to prefer military solutions to political compromises in resolving violent conflicts.

\begin{abstract}
A cross the Arab Middle East, violent conflicts have wreaked unfathomable damage, bringing levels of death, destruction, and displacement not seen since World War II. Their effects will be felt for generations. For scholars, officials, and practitioners, moreover, the region's civil wars pose significant challenges. They test the limits of current practice in postconflict reconstruction. They also test the limits of key findings in the research literature on civil war. In three major respects, civil wars in the Middle East call into question assumptions that have shaped theory and practice concerning the political economy of civil wars, on one hand, and the options available for building pathways out of conflict and toward postconflict reconstruction and social repair, on the other hand. All three challenges to conventional wisdom flow from observed continuities in governance norms and practices
\end{abstract} between prewar and wartime conditions.

First, the experience of violent conflict in the Middle East suggests that civil war does not mark a rupture or breakdown of prewar practices of economic governance. Nor can we view rebel economic governance as exhibiting attributes that distinguish it from those of regimes. Rather, conflict is marked by high levels of continuity between prewar and wartime practices of economic governance, with high levels of similarity in the behavior of both regimes and insurgents.

Second, the continuity of governance practices between prewar and wartime con- ditions weakens the claims of practitioners Steven who embrace the notion of state fragility, view conflict as signaling the breakdown of a prewar institutional order, and link prospects for postwar reconstruction to reforms designed to endow postwar institutions with the capacities associated with idealized notions of good governance (transparency, inclusion, accountability, and participation). Civil wars in the Middle East highlight how remote and implausible such notions are as guides to feasible strategies for ending violent conflict. They also underscore the robustness of prewar institutional arrangements, and the extent to which they are seen as assets by warring parties.

Third, continuity in governance practices sheds light on the limits of efforts to treat governance and sovereignty as separable or loosely coupled under conditions of limited statehood. It calls attention to the imperative that recognized authorities face to assert and defend a rigid, unitary, and Westphalian conception of sovereignty, and the extent to which continuity in the provision of governance becomes a marker of sovereignty. Under such conditions, there is little reason to be optimistic about peace-building strategies that would require recognized authorities to compromise their claims to sovereignty.

This analysis of the implications of continuity in prewar and wartime governance practices in three civil wars currently underway in the Middle East leads to sobering conclusions. Governance practices institutionalized by authoritarian regimes prior to conflict have proven decisive in shaping important wartime behaviors of regimes and insurgents in all three cases. Degrees of continuity vary in ways yet to be explored. With respect to economic governance in particular, however, the emergence of wartime economic orders has produced similar governance strategies across conflict lines, with armed actors relying heavily on coercion, predation, criminality, the selective allo- 
Civil War, cation of public goods, and the dispersion

Economic

Governance \&

State Reconstruction in the

Arab Middle

East of sovereign economic functions to external and nonstate actors. Under these conditions, we should anticipate that civil wars in the Middle East will not yield easily to negotiated solutions. We should also expect that the eventual outcomes of conflict are unlikely to produce durable peace, political stability, or economic well-being for citizens. In addition, the extent to which repressive and exclusionary wartime economic orders reflect institutionalized economic norms and practices, and have empowered armed actors whose interests are served by the continuation of conflict, make these cases poor candidates for external interventions defined in terms of overcoming state fragility. They are also likely to feature the abuse of sovereignty norms to exacerbate maximalist claims by regimes and insurgent challengers alike.

Pathways out of civil war in such cases are particularly elusive. They are likely to require diplomatic, financial, and military strategies that create incentives for embattled regimes and insurgent challengers to end violence and accept meaningful compromises in the interest of securing their minimal requirements, and these may well include the absence of transitional justice and accountability for perpetrators, as well as power-sharing arrangements that accommodate all warring parties to differing degrees. As violent conflicts in Libya, Syria, and Yemen rage on, however, such outcomes still appear stubbornly out of reach.

\section{ENDNOTES}

${ }^{1}$ Didier Péclard and Delphine Mechoulan, "Rebel Governance and the Politics of Civil War," Working Paper (Basel, Switzerland: Swiss Peace Foundation, 2015).

${ }^{2}$ U.S. Agency for International Development, Measuring Fragility: Indicators and Methods for Rating State Performance (Washington, D.C.: U.S. Agency for International Development, 2005); and Robert I. Rotberg, ed., When States Fail: Causes and Consequences (Princeton, N.J. : Princeton University Press, 2003).

3 Michael Woolcock, "Engaging with Fragile and Conflict-Affected States: An Alternative Approach to Theory, Measurement and Practice," Working Paper No. 286 (Helsinki : World Institute for Development Economics Research, 2014); and William J. Burns, Michèle Flournoy, and Nancy Lindborg, U.S. Leadership and the Challenge of State Fragility (Washington, D.C. : United States Institute of Peace, 2016).

4 William Reno, "Fictional States \& Atomized Public Spheres: A Non-Western Approach to Fragility,” Doedalus 146 (4) (Fall 2017).

5 Ariel Ahram, "Learning to Live with Militias: Toward a Critical Policy on State Failure," Journal of Intervention and State Building 5 (2) (2011): 179.

${ }^{6}$ Tanja A. Börzel and Sonja Grimm, "Building Good (Enough) Governance in Postconflict Societies \& Areas of Limited Statehood: The European Union \& the Western Balkans," Dacdalus 147 (1) (Winter 2017).

7 This theme is addressed by several other authors in this issue of Dadalus. See also Thomas Risse, ed., Governance without a State? Policies and Politics in Areas of Limited Statehood (New York: Columbia University Press, 2011); and Stephen Krasner, Sovereignty: Organized Hypocrisy (Princeton, N.J. : Princeton University Press, 1999).

${ }^{8}$ Benjamin Miller, "Balance of Power or the State-to-Nation Balance: Explaining Middle East War-Propensity," Security Studies 15 (4) (2006): 658-705.

9 Nicholas Sambanis, "Partition as a Solution to Ethnic War: An Empirical Critique of the Theoretical Literature," World Politics 52 (4) (2000): 437-483; Chaim Kaufmann "When All Else 
Fails : Ethnic Population Transfers and Partitions in the Twentieth Century," International Se- Steven curity 23 (2) (1998): 129-156; and Nicholas Sambanis and Jonah Schulhofer-Wohl, "What's Heydemann in a Line? Is Partition a Solution to Civil War?" International Security 34 (2) (2009): 82 - 118.

10 Hendrik Spruyt, "Civil Wars as Challenges to the Modern International System," Dodalus 146 (4) (Fall 2017).

${ }^{11}$ Paul Staniland, Networks of Rebellion: Explaining Insurgent Cohesion and Collapse (Ithaca, N.Y.: Cornell University Press, 2014), 218.

12 Wolfram Lacher, “Libya: A Jihadist Growth Market," in Jihadism in Africa: Local Causes, Regional Expansion, International Alliances, ed. Guido Steinberg and Annette Weber (Berlin : Stiftung Wissenschaft und Politik, 2015), $31-50$.

13 International Crisis Group, The Prize: Fighting for Libya's Energy Wealth, Middle East and North Africa Report No. 165 (Brussels: International Crisis Group, 2015).

14 Reno, "Fictional States \& Atomized Public Spheres"; and Vanda Felbab-Brown, "Organized Crime, Illicit Economies, Civil Violence \& International Order: More Complex Than You Think," Doedalus 146 (4) (Fall 2017).

15 Masha Hedberg, “Top-Down Self-Organization : State Logics, Substitutional Delegation, and Private Governance in Russia," Governance 29 (1) (2016): 67 - 83 ; and Béatrice Hibou, The Force of Obedience: The Political Economy of Repression in Tunisia (Cambridge: Polity, 2011).

16 April Alley, "The Rules of the Game: Unpacking Patronage Politics in Yemen," Middle East Journal 64 (3) (2010):385 - 409; and Dirk Vandewalle, Libya Since Independence: Oil and State Building (Ithaca, N.Y.: Cornell University Press, 1998).

${ }^{17}$ Ariel Ahram, Proxy Warriors: The Rise and Fall of State-Sponsored Militias (Stanford, Calif. : Stanford University Press, 2011); Adnan Naseemullah, "Shades of Sovereignty: Explaining Political Order and Disorder in Pakistan's Northwest," Studies in Comparative International Development 49 (4) (2014): 501 - 522; and Janet Roitman, Fiscal Disobedience: An Anthropology of Economic Regulation in Central Africa (Princeton, N.J. : Princeton University Press, 2005).

${ }^{18}$ Karen Ballentine and Jake Sherman, eds., The Political Economy of Armed Conflict: Beyond Greed and Grievance (Boulder, Colo.: Lyne Rienner Publishers, 2003), 2-3 (emphasis mine).

19 Daniel Brumberg, “Transforming the Arab World's Protection-Racket Politics,” Journal of Democracy 24 (3) (2013): $88-103$.

20 Zachariah C. Mampilly, Rebel Rulers: Insurgent Governance and Civilian Life during War (Ithaca, N.Y.: Cornell University Press, 2011).

${ }^{21}$ Nelson Kasfir, "Domestic Anarchy, Security Dilemmas, and Violent Predation : Causes of Failure," in Rotberg, ed., When States Fail: Causes and Consequences.

${ }^{22}$ Steven Heydemann, "Upgrading Authoritarianism in the Arab World," The Saban Center for Middle East Policy Analysis Paper No. 14 (Washington, D.C.: The Brookings Institution, 2007).

23 Bassam Haddad, Business Networks in Syria: The Political Economy of Authoritarian Resilience (Stanford, Calif.: Stanford University Press, 2012).

${ }^{24}$ Reinoud Leenders and Steven Heydemann, "Popular Mobilization in Syria: Opportunity and Threat, and the Social Networks of the Early Risers," Mediterranean Politics 17 (2) (2012): 139 - 159.

25 The People Demand Change interview with Qutaiba Idlibi, Washington, D.C., August 19, 2016.

${ }^{26}$ Cody Roche, “Assad Regime Militias and Shi'ite Jihadis in the Syrian Civil War,” BellingCat, November 30, 2016, https://www.bellingcat.com/news/mena/2016/11/30/assad-regime -militias-and-shiite-jihadis-in-the-syrian-civil-war/; and Raja Abdulrahim, "In Syria, Patchwork of Forces Control Regime-Held Areas," Wall Street Journal, March 7, 2017, https ://www .wsj.com/articles/in-syria-patchwork-of-forces-control-regime-held-areas-1488882600. 
Civil War,

Economic

Governance \&

State Recon-

struction in the

Arab Middle

East

27 Tobias Schneider, "The Decay of the Syrian Regime is Much Worse than You Think," War On The Rocks, August 31, 2016, http://warontherocks.com/2016/o8/the-decay-of-the-syrian -regime-is-much-worse-than-you-think/.

${ }^{28}$ Hamad al-Mahmoud, "The War Economy in the Syrian Conflict: The Government's HandsOff Tactics," Carnegie Endowment for International Peace, December 15, 2015, http ://carnegie endowment.org/2015/12/15/war-economy-in-syrian-conflict-government-s-hands-off-tactics -pub-62202.

29 Erika Solomon, “Syria Crisis: In Homs ‘Sunni Markets’ Sell Looted Goods,” Reuters, June 19, 2012, http://www.huffingtonpost.com/entry/homs-sunni-markets_n_1608009?utm_hpref=tw.

${ }^{30}$ Rim Turkmani, Ali A. K. Ali, Mary Kaldor, and Vesna Bojicic-Dzelilovic, Countering the Logic of the War Economy in Syria: Evidence from Three Local Areas (London : London School of Economics and Political Science, 2015), http://www.securityintransition.org/wp-content/uploads /2015/08/Countering-war-economy-Syria2.pdf.

${ }^{31}$ Omer Karasapan, "The Impact of Syrian Businesses in Turkey,” The Brookings Institution, March 16, 2016, https://www.brookings.edu/blog/future-development/2016/03/16/the-impact -of-syrian-businesses-in-turkey/.

${ }^{22}$ Mattia Toaldo, "Migrations through and from Libya : A Mediterranean Challenge," Working Paper 15/14 (Rome: Istituto Affari Internazionali, 2015), 3.

33 Atlantic Council interview with Karim Mezran, Washington, D.C., January 12, 2017.

34 U.S. Embassy Sana'a, “ROYG Insiders Increasingly Frustrated with Saleh Clan,” Wikileaks Cable: 05SANAA1352_a, May 23, 2005, https://wikileaks.org/plusd/cables/o5SANAA1352_a.html.

35 Freedom House, “Freedom in the World: Yemen," https ://freedomhouse.org/report/freedom -world/2016/yemen.

${ }^{36}$ United Nations High Commissioner for Refugees, Yemen Situation:Regional Refugee and Migrant Response Plan (Geneva: United Nations High Commissioner for Refugees, 2015), http://reporting .unhcr.org/node/9982.

37 Steven Heydemann, "Social Pacts and the Persistence of Authoritarianism in the Middle East," in Debating Arab Authoritarianism, ed. Oliver Schlumberger (Stanford, Calif. : Stanford University Press, 2007), 22 - 38 ; and Steven Heydemann and Reinoud Leenders, eds., Middle East Authoritarianisms: Governance, Contestation, and Regime Resilience in Syria and Iran (Stanford, Calif. : Stanford University Press, 2013).

${ }^{38}$ Kheder Khaddour, How Regional Security Concerns Uniquely Constrain Governance in Northeast Syria (Beirut: Carnegie Endowment for International Peace, 2017), 1, http://carnegieendowment .org/files/CMEC_66_Khaddour_Jazira_FInal_Web.pdf.

39 Leonard Wantchekon, "The Paradox of 'Warlord' Democracy: A Theoretical Investigation," American Political Science Review 98 (1) (2004): 18.

40 Reyko Huang, The Wartime Origins of Democratization: Civil War, Rebel Governance, and Political Regimes (Cambridge: Cambridge University Press, 2016).

${ }^{41}$ Danya Greenfield and Svetlana Milbert, "Protests in Yemen Expose Weak Governance and Poor Economic Planning," Atlantic Council, September 2, 2014, http://www.atlanticcouncil.org/blogs/ menasource/protests-in-yemen-expose-weak-governance-and-poor-economic-planning.

${ }^{42}$ International Crisis Group, The Prize.

43 Schneider, "The Decay of the Syrian Regime is Much Worse Than You Think."

44 Steven Heydemann, “Tracking the Arab Spring: Syria and Arab Authoritarianism," Journal of Democracy 24 (4) (2013): $59-73$.

45 Nick Hopkins and Emma Beals, "UN Pays Tens of Millions to Assad Regime under Syria Aid Programme,” The Guardian, August 29, 2016, https://www.theguardian.com/world/2016/ aug/29/un-pays-tens-of-millions-to-assad-regime-syria-aid-programme-contracts. 
47 Aila M. Matanock, “Governance Delegation Agreements : Shared Sovereignty as a Substitute for Limited Statehood,” Governance 27 (4) (2014): 589-612; and Stephen Krasner and Thomas Risse, "External Actors, State-Building, and Service Provision in Areas of Limited Statehood: Introduction,” Governance 27 (4) (2014): 545-567.

${ }^{48}$ Reinoud Leenders, "Prosecuting Political Dissent Courts and the Resilience of Authoritarianism in Syria," in Middle East Authoritarianisms: Governance, Contestation, and Regime Resilience in Syria and Iran, ed. Steven Heydemann and Reinoud Leenders (Stanford, Calif. : Stanford University Press, 2013), 169-199; and Tom Ginsberg and Alberto Simpser, eds., Constitutions in Authoritarian Regimes (Cambridge: Cambridge University Press, 2013).

49 Thomas Risse, “Governance under Limited Sovereignty,” in Back to Basics: State Power in the Contemporary World, ed. Martha Finnemore and Judith Goldstein (Oxford: Oxford University Press, 2013), $78-104$.

50 Krasner, Sovereignty. 
Copyright of Daedalus is the property of MIT Press and its content may not be copied or emailed to multiple sites or posted to a listserv without the copyright holder's express written permission. However, users may print, download, or email articles for individual use. 